\title{
The World Economy since the War
}




\begin{abstract}
Also by E. A. Brett
Colonialism and Underdevelopment in East Africa

International Money and Capitalist Crisis
\end{abstract}




\title{
The World Economy since the War
}

The Politics of Uneven Development

\author{
E. A. Brett
}

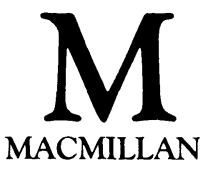


All rights reserved. No reproduction, copy or transmission of this publication may be made without written permission.

No paragraph of this publication may be reproduced, copied or transmitted save with written permission or in accordance with the provisions of the Copyright Act 1956 (as amended).

Any person who does any unauthorised act in relation to this publication may be liable to criminal prosecution and civil claims for damages.

First published 1985

Published by

Higher and Further Education Division

MACMILLAN PUBLISHERS LTD

Houndmills, Basingstoke, Hampshire RG21 2XS

and London

Companies and representatives

throughout the world

Filmsetting by Vantage Photosetting Co Ltd, Eastleigh and London

British Library Cataloguing in Publication Data

Brett, E. A.

The world economy since The War: the politics of uneven development.

1. Economic history-1945 - 2. Economic development

I. Title

\section{9'04 HC59}

ISBN 978-0-333-37200-5

ISBN 978-1-349-17896-4 (eBook)

DOI 10.1007/978-1-349-17896-4 
FOR JULIE

In the hope that Adam, Katie and Adi may have a future 


\section{Contents}

Preface ix

Introduction: Understanding the International Crisis 1

PART I THE THEORY AND STRUCTURE OF INTERNATIONAL ECONOMIC ORGANISATION

1 A Political Theory for the World Market 13

2 Economic Theories of the World Market 30

Free market theory $\quad 32$

International Keynesianism $\quad 47$

Protectionism and import substitution $\quad 51$

Marxism $\quad 56$

3 The Post-War Political Settlement 62

The International Monetary Fund 65

The World Bank $\quad 73$

The General Agreement on Tariffs and Trade $\quad 74$

4 Multinational Corporations, Nation States, World

$\begin{array}{ll}\text { Economy } & 80\end{array}$

PART II THE INDUSTRIAL COUNTRIES IN THE INTERNATIONAL SYSTEM

5 American Deficits, Global Boom and Crisis 105

Financing the post-war boom, 1947-1961 105

Reform and crisis, 1961-1973 111

From crisis to crisis, 1974-1984 125

6 Britain's International Decline 132

The social democratic foundations, 1945-1950 134

The contradictions of liberalisation, 1951-1968 148

Disintegration, 1969-1976 156

Liberalism in crisis, 1976-1984 165

$\begin{array}{lr}\text { Evaluation } & 170\end{array}$ 
viii Contents

PART III UNDERDEVELOPMENT IN THE INTERNATIONAL SYSTEM

$\begin{array}{ll}\text { Prologue } & 177\end{array}$

7 Policies and Developments in the Third World 182

The long boom, 1945-1971 182

The crisis years, 1971-1984 193

Conclusions 199

8 The LDCs and the Official Agencies 207

Integration into the international system, 1945-1971 207

Dealing with crisis, 1971-1984 212

9 Private Banks, LDC Debt, Global Disequilibrium 229

Conclusion: Out of Anarchy? 249

Notes and References

Index 


\section{Preface}

This book attempts to provide a general assessment of the political implications of the present crisis in the world economy. It should be looked at alongside my earlier International Money and Capitalist Crisis (London, 1983) since it depends upon some of the theoretical arguments presented there, but it is intended to broaden the scope of those arguments and develop the empirical material required to substantiate them. However, to ensure that this volume can also stand alone, some of the general issues treated there are also covered here, hopefully in a more accessible form with the most complex technicalities removed. It, too, excludes any consideration of the problem of East-West relations and the internal structure of the socialist bloc, but covers a number of areas (the role of multinationals, the decline of the British economy, and the international dimension of the development problem) which could not be treated adequately there because of its focus on monetary problems.

Although the book will probably serve primarily as a textbook, the problems that it addresses are not of purely academic concern. International instability and recession are having the most devastating effects upon the welfare and future prospects of all of us, and are therefore the subject of intense and necessarily highly partisan debate. This book attempts to present this debate without doing serious injustice to any of the views involved, even where its final conclusion has been to reject them. But it does not aspire to an apolitical academic detachment, but is intended to counter the liberal view of the functioning of the capitalist international system which now dominates orthodox political science and economics and sustains the efforts at reform being organised by the establishment. Having reviewed the evidence as dispassionately as possible, it therefore concludes by asserting the validity of a socialist vision which stands in direct opposition to the atomistic views of liberal orthodoxy. And although it rests heavily upon the Marxist critique of that view, much of the analysis does not depend upon a Marxist fundamentalism, but should be equally acceptable to those who are 
prepared to go no further than radical variants of Keynesianism. It is therefore intended as both a political and an academic intervention in the devout hope that the two are not inherently incompatible. After all, The Wealth of Nations was written to provide a rational resolution of the major political controversy of the day, that between Whigs and Tories in Scotland, but is nevertheless still used as a text in even the most respectable universities.

Many people have contributed to the development of the argument and the final text - the former emerged out of general discussions with Andy Pople, Mike Hall and Steve Gilliatt, the latter has been greatly improved through comments from Steven Kennedy, Andrew Gamble, Susan Cunningham and Robert Wade. I am also particularly grateful to Jeremy Beale for producing the index, and to Helen Warner for typing the original manuscript. Responsibility for the errors and omissions is, needless to say, entirely my own.

Brighton

E. A. Brett

Acknowledgement. The author and publishers are grateful to the Department of Applied Economics, University of Cambridge, for permission to reproduce data from The British Economy, Key Statistics, 1900-66. 